\title{
Urinary excretion of catechin metabolites by human subjects after red wine consumption
}

\author{
Jennifer L. Donovan ${ }^{1}$, Sidika Kasim-Karakas ${ }^{2}$, J. Bruce German ${ }^{3}$ and Andrew L. Waterhouse ${ }^{1}$ \\ Departments of ${ }^{1}$ Viticulture and Enology, ${ }^{2}$ Endocrinology and Metabolism and ${ }^{3}$ Food Science and Technology, University of \\ California, Davis, California 95616, USA
}

(Received 1 May 2001 - Revised 25 July 2001 - Accepted 31 August 2001)

\begin{abstract}
Little is known about flavonoid metabolism and excretion in man. In the present study, the urinary excretion of a major flavonoid in wine, catechin, and its metabolites, were measured after nine human subjects each consumed $120 \mathrm{ml}$ red wine (RW) on one day and de-alcoholized red wine (DRW) on a separate day. Both the RW and DRW contained 120 (SEM 3) $\mu$ mol catechin $(35 \mathrm{mg})$. GC-MS analyses of the trimethylsilylated derivatives of catechin and $3^{\prime}$ and $4^{\prime}$ methylcatechin were performed before and after hydrolysis of conjugates by $\beta$-glucuronidase and sulfatase. Baseline urine samples collected prior to wine consumption contained 0.013 (SEM $0.005) \mu \mathrm{mol}$ catechin and metabolites. During the $8 \mathrm{~h}$ period following consumption of RW and DRW, 6.6 (SEM 0.9) and 5.3 (SEM 0.6) $\mu \mathrm{mol}$ catechin and metabolites were excreted in 893 (SEM 94) and 740 (SEM 101) $\mathrm{ml}$ urine respectively. This corresponded to $3 \cdot 0-10 \cdot 3 \%$ of the dose after RW and $2 \cdot 1-8.2 \%$ of the dose after DRW. The amount of catechin and metabolites excreted in urine was $20 \%$ higher after RW compared with DRW $(P=0 \cdot 06)$. Catechin in all urine samples was present as metabolites and there were no differences in the proportions of individual metabolites after RW and DRW. As with other flavonoids, the fate of most ingested catechin is not yet known.
\end{abstract}

Wine: Catechin: Catechin metabolites: Urinary excretion: Man

Flavonoids are abundant components of fruits, vegetables, red wine, tea and chocolate (Kühnau, 1976; Scalbert \& Williamson, 2000; Arts et al. 2001). They display a multitude of biological effects in vitro and in vivo after consumption of flavonoid-containing foods (Walle et al. 1995; Clifford et al. 1996; So et al. 1996; Teissedre et al. 1996; Da Silva et al. 1998; Nidgikar et al. 1998; Day et al. 2000; Rein et al. 2000a, b; Young et al. 2000; Schramm et al. 2001). Epidemiologic studies show strong associations between consumption of flavonoid-containing foods, especially wine, and reduced mortality from cardiovascular disease (St Leger et al. 1979; Hertog et al. 1993; Klatsky \& Armstrong, 1993; Criqui \& Ringel, 1994; Sasaki \& Kesteloot, 1994; Grønbæk et al. 1995; Hertog et al. 1995; Renaud \& de Lorgeril, 1992).

Little is known about flavonoid metabolism, distribution and excretion after consumption of common foods. There have been some clinical studies reporting the absorption and excretion of flavonols (Hollman et al. 1995, 1997; de Vries et al. 1998, 2001; Manach et al. 1998; flavones (Nielsen et al. 1999), anthocyanins (Lapidot et al. 1998), flavanones (Fuhr \& Kummert, 1995), flavanols (Lee et al. 1995; Richelle et al. 1999; Rein et al. 2000a) and isoflavonoids (Xu et al. 1994, 1995; Ameer et al. 1996) after consumption from food sources. However, the vast majority of studies were performed using gram-size doses, which gives little insight into the fate of flavonoids when consumed in smaller quantities as food constituents (Das, 1971; Das \& Sothy, 1971; Gugler et al. 1975; Shaw \& Griffiths, 1980; Shaw et al. 1982; Hackett et al. 1983; Wermeille et al. 1983).

The present study focused on the urinary excretion of the flavonoid catechin and its metabolites following consumption of a single serving of red wine (RW) or de-alcoholized red wine (DRW). Catechin was chosen as the flavonoid of interest because it is a major wine flavonoid and it is found in many different foods (Hollman \& Arts, 2000; Arts et al. 2000a,b; de Pascual-Teresa et al. 2000). Studies have shown its potent antioxidant activity in vitro (Teissedre et al. 1996; Plumb et al. 1998) and its efficacy in reducing atherogenesis in an animal model (Xu et al. 1998).

\footnotetext{
Abbreviations: DRW, de-alcoholized red wine; $3^{\prime} \mathrm{MC}, 3^{\prime}-O$-methylcatechin; 4'MC, 4'-O-methylcatechin; RW, red wine containing alcohol.

* Corresponding author: Dr Jennifer L. Donovan, present address Laboratory of Drug Disposition and Pharmacogenetics, Department of Psychiatry, Room 246N, Medical University of South Carolina, 67 President Street, Charleston, SC 29425, USA, fax +1 843792 6318, email donovanj@musc.edu
} 
There are no previous reports of the urinary excretion of catechin after doses that are normally present in wine or foods. Earlier studies on the urinary excretion of catechin by human subjects used large doses of purified catechin. Das (1971) recovered $8 \%$ of a $4 \mathrm{~g}$ dose as catechin and its glucuronide and sulfate conjugates over $24 \mathrm{~h}$, most of which were excreted during the first 6 h. Hackett et al. (1983) also measured the excretion of methylated catechin metabolites and reported that $48 \%$ of a $2 \mathrm{~g}$ dose was recovered in urine as conjugates of catechin or methylated catechin over a $24 \mathrm{~h}$ period.

The pharmacokinetics of catechin and its metabolites in human plasma after consumption of RW and DRW have been reported (Donovan et al. 1999a). In that study, catechin metabolites reached a concentration of $100 \mathrm{nmol} / \mathrm{l}$ plasma $1 \mathrm{~h}$ after a single serving of RW. When the results were compared with those of earlier studies that used larger doses, it was apparent that the dose influenced both the amount of catechin in plasma as well as the pattern of catechin metabolites. Few differences were observed between the amounts of metabolites in plasma after consumption of RW and DRW. Ethanol in RW, however, reduced the elimination half-life of metabolites from plasma. Thus, it is important to determine if ethanol also has an effect on urinary elimination. The present study reports the urinary excretion of catechin and its metabolites in the same human subjects over an $8 \mathrm{~h}$ period after RW and DRW consumption.

\section{Methods}

\section{Chemicals and reagents}

(+)-Catechin was obtained from Fluka Chemicals (Ronkonkoma, NY, USA) and (+)-taxifolin from Apin Chemicals Ltd (Abingdon, Oxford, UK). $3^{\prime}-O$-methylcatechin $\left(3^{\prime} \mathrm{MC}\right)$ and $4^{\prime}-O$-methylcatechin $\left(4^{\prime} \mathrm{MC}\right)$ were synthesized, purified and identified as previously described (Donovan et al. $1999 b$ ). The derivatizing reagent, N,O-bis(trimethylsilyl)trifluoroacetamide, was purchased from Pierce (Rockford, IL, USA). $\beta$-Glucuronidase (G-0376), aryl sulfatase (S9754) and D-saccharic acid 1-4 lactone were purchased from Sigma Chemical Co. (St Louis, MO, USA). All solvents and reagents were Fisher HPLC or Optima grade, and other reagents were either purchased from Fisher (Pittsburgh, PA, USA) or Aldrich (Milwaukee, WI, USA).

\section{Subjects and study design}

The experimental design, preparation and analysis of the RW and DRW, and the human subject selection criteria have been described previously (Donovan et al. 1999a; Bell et al. 2000). Briefly, nine volunteers (Five men, Four women, age 29 (SEM 3) years, weight 78 (SEM 4) kg consumed a flavonoid-free diet for $2 \mathrm{~d}$ prior to ingestion of wine. After a $14 \mathrm{~h}$ fast, a baseline urine sample was collected from each subject who then consumed, in random order, $120 \mathrm{ml}$ either RW or DRW (100\% Cabernet Sauvignon, 1996), providing 120 (SEM 3) $\mu$ mol of (+)catechin (35 mg) as analysed by HPLC (Ritchey \& Waterhouse, 1999). The RW contained $103 \mathrm{~g} / \mathrm{l}$ ethanol and provided $12.4 \mathrm{~g}$ ethanol in $120 \mathrm{ml}$. The crossover design allowed each subject to serve as his or her own control. Each subject consumed the second wine sample after resuming the flavonoid-free diet for at least $2 \mathrm{~d}$. The subjects urinated as needed over the $8 \mathrm{~h}$ time period but were asked to empty their bladders near $8 \mathrm{~h}$. The individual specimens were collected in plastic cups and the time and volume of each urine collection was recorded. A $1 \mathrm{ml}$ aliquot of urine was mixed with $25 \mu \mathrm{l}$ phosphate-buffered ascorbic acid $(0.4 \mathrm{~mol}$ $\mathrm{NaH}_{2} \mathrm{PO}_{4} / 1,200 \mathrm{~g}$ ascorbic acid/l, $1 \mathrm{~g}$ EDTA/l, pH 3.6) and was flushed with $\mathrm{N}_{2}$ and immediately frozen at $-70^{\circ} \mathrm{C}$. The clinical protocol was approved by the Human Subjects Committee at the University of California at Davis.

\section{Analysis of urine}

To prevent oxidation of the analytes during sample preparation, all solvents and reagents were deoxygenated by purging with $\mathrm{N}_{2}$ and were kept cold during extraction. The samples were thawed and $20 \mu l$ urine were mixed with $450 \mu \mathrm{l}$ sodium acetate buffer $(50 \mathrm{mmol} / \mathrm{l}, \mathrm{pH} 5 \cdot 5)$ and $250 \mu \mathrm{l}$ $\mathrm{CaCl}_{2}(0.6 \mathrm{~mol} / \mathrm{l})$. Taxifolin was used as an internal standard and a final concentration of $20 \mu \mathrm{mol} / 1$ was added to all urine samples. Samples for measurement of total catechin, total $3^{\prime} \mathrm{MC}$ and total $4^{\prime} \mathrm{MC}$ were incubated at $37^{\circ} \mathrm{C}$ in a shakerwater bath for $1 \mathrm{~h}$ in $\mathrm{N}_{2}$-flushed tubes containing 100 units sulfatase and 2500 units $\beta$-glucuronidase dissolved in $120 \mu \mathrm{l}$ water. Individual conjugate forms were determined after incubation without enzymes (free), or with $\beta$ glucuronidase (glucuronide conjugates), or with sulfatase and $0 \cdot 2 \mathrm{~mol}$ saccharic acid 1,4 lactone/l (sulfate conjugates). Conjugates containing both the glucuronide and sulfate residues were then estimated by subtracting the free, sulfate and glucuronide forms from the total values.

After incubation, the urine was extracted with $2 \mathrm{ml}$ ethyl acetate and centrifuged at $4500 \mathrm{~g}$ for $3 \mathrm{~min}$ at $4^{\circ} \mathrm{C}$. The supernatant fraction was removed and the remaining fraction was extracted a second time with $1.5 \mathrm{ml}$ ethyl acetate. The combined ethyl acetate extracts were passed through anhydrous sodium sulfate packed in a Pasteur pipette, dried under $\mathrm{N}_{2}$, redissolved in $20 \mu \mathrm{l}$ pyridine and derivatized with $30 \mu \mathrm{l}, \mathrm{O}$-bis (trimethylsilyl)-trifluoroacetamide at $65-75^{\circ} \mathrm{C}$ for $2 \mathrm{~h}$.

GC-MS analyses were performed on a Hewlett-Packard 6890 GC equipped with a 5973 quadropole MS and a DB-23 capillary GC column $(60 \mathrm{~m} \times 0.25 \mathrm{~mm}$ i.d., $0.25 \mu \mathrm{m}$ film thickness; J \& W Scientific, Folsom, CA, USA). Injections of $1 \mu \mathrm{l}$ were made and the column temperature was programmed from $170^{\circ} \mathrm{C}(3 \mathrm{~min}$ hold $)$ to $255^{\circ} \mathrm{C}$ at $12^{\circ} \mathrm{C} / \mathrm{min}$ and held for $12 \mathrm{~min}$. The column was then cooled to $245^{\circ} \mathrm{C}$ at $5^{\circ} \mathrm{C} / \mathrm{min}$ and held for $6 \mathrm{~min}$ before the next analysis. The He carrier gas flow rate was $0.7 \mathrm{ml} / \mathrm{min}$ with an average linear velocity of $23 \mathrm{~cm} / \mathrm{min}$. Major fragmentation ions and molecular ions for catechin $(\mathrm{m} / \mathrm{z}=368650), 3^{\prime} \mathrm{MC}$ and $4^{\prime} \mathrm{MC}(\mathrm{m} / \mathrm{z}=310592)$ and taxifolin $(\mathrm{m} / \mathrm{z}=368664)$ were monitored in selective-ion monitoring mode using a dwell time of $100 \mathrm{~ms} / \mathrm{channel}$.

For quantitation, standard curves were prepared in blank urine (i.e. urine containing undetectable levels of the analytes). Catechin, $3^{\prime} \mathrm{MC}$ and $4^{\prime} \mathrm{MC}$ were added to the blank urine at final concentrations ranging from 0.2 to 
$34.4 \mu \mathrm{mol} / \mathrm{l}$. Taxifolin was added at a final concentration of $20 \mu \mathrm{mol} / \mathrm{l}$. The urine was then incubated without addition of enzymes, extracted and analysed as described for the samples. Standard curves were linear and had average $r^{2}$ values of 0.998. The slopes of five standard curves prepared over $10 \mathrm{~d}$ varied $<5 \%$ (CV). The limit of detection (signal: noise $=3$ ) was $30 \mathrm{nmol} / 1$ for all three analytes. Reproducibility was determined by ten separate analyses of a single urine sample over a 1-month period. The method had an average $\mathrm{CV}$ of $11.9 \%$ for catechin, $3^{\prime} \mathrm{MC}$ and $4^{\prime} \mathrm{MC}$.

\section{Statistical analysis}

Concentrations of catechin metabolites in urine were multiplied by the respective urinary volume to obtain the amount excreted during a given sampling time. All values are expressed as mean values with the standard errors for the nine subjects. Each subject served as his or her own control in this study and levels of catechin metabolites after RW and DRW were compared for each subject using the paired $t$ test. To determine the changes in metabolite composition over time, the differences in the percentages of the individual conjugate forms in the first urine sample (near $1 \mathrm{~h}$ ) were compared with the percentages in the final urine sample (near $8 \mathrm{~h}$ ) using the paired $t$ test.

\section{Results}

\section{Urine volumes}

Volumes of urine collected prior to RW and DRW consumption were 55 (SEM 13) and 70 (SEM 22) $\mathrm{ml}$ respectively. The average number of urine samples during the $8 \mathrm{~h}$ collection period after RW and DRW consumption was 4 (SEM 1). The total volumes of urine collected during the $8 \mathrm{~h}$ period after RW and DRW consumption were 893 (SEM 94) and 740 (SEM 101) $\mathrm{ml}$ respectively $(P=0 \cdot 1)$.

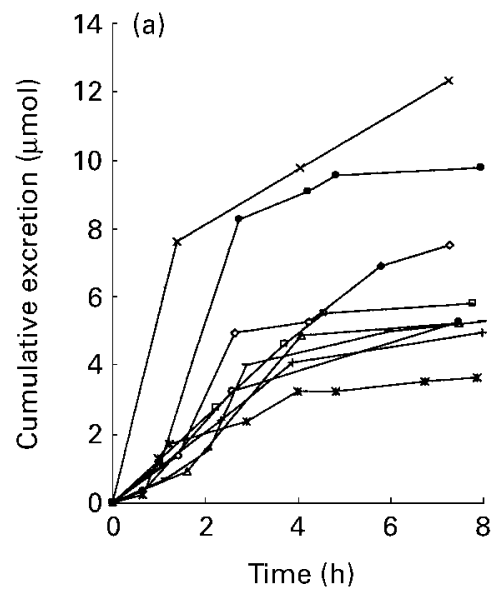

\section{Total excretion of catechin}

Urine samples collected before RW and DRW consumption respectively contained a total of 0.008 (SEM 0.003) and 0.020 (SEM 0.007) $\mu \mathrm{mol}$ total catechin (catechin and all measured metabolites). The cumulative excretion of total catechin in the urine of each subject over the $8 \mathrm{~h}$ period after RW and DRW consumption is shown in Fig. 1. The amount of total catechin in all samples increased as early as $30 \mathrm{~min}$ after both RW and DRW. Total catechin excreted over the $8 \mathrm{~h}$ period was $20 \%$ higher $(P=0 \cdot 06)$ after RW than after DRW. Subjects excreted a total of 6.6 (SEM 0.9) $\mu \mathrm{mol}$ after RW and $5 \cdot 3$ (SEM 0.6) $\mu \mathrm{mol}$ after DRW. Subjects varied in the percentage of the catechin dose excreted over the $8 \mathrm{~h}$ period, and values ranged from 3.0 to $10.3 \%$ after RW and from 2.1 to $8.2 \%$ after DRW. The urine samples that contained the largest quantities of total catechin were collected $2-4 \mathrm{~h}$ after RW and DRW consumption, containing an average of 3.7 (SEM 0.7) and 2.9 (SEM 0.7) $\mu \mathrm{mol}$ respectively.

\section{Metabolites of catechin}

The total amounts of the individual forms of catechin metabolites excreted over the $8 \mathrm{~h}$ period after RW and DRW consumption are shown in Table 1 . The amount of free, native catechin was extremely low and always accounted for $<0.3 \%$ total catechin metabolites. There were no significant differences in the percentages of the individual conjugate forms after consumption of RW and DRW.

Sulfated conjugates of catechin accounted for 40 (SEM 4) $\%$ total metabolites in urine after RW and 42 (SEM 6) \% after DRW. Catechin was also excreted in a form with both glucuronide and sulfate and these accounted for 37 (SEM 4) $\%$ after RW and 35 (SEM 6) \% after DRW. Only a small amount of catechin was excreted as a glucuronide conjugate.

Catechin was also methylated in the $3^{\prime}$ position. Over the $8 \mathrm{~h}$ urine collection period, 19 (SEM 2) and 18 (SEM 1) \% of the total metabolites were methylated in the $3^{\prime}$ position after

Fig. 1. Cumulative excretion of catechin and its metabolites by nine human subjects over an $8 \mathrm{~h}$ period following consumption of (a) $120 \mathrm{ml}$ red wine (RW) or (b) $120 \mathrm{ml}$ de-alcoholized red wine (DRW). For details of subjects and procedures, see p. 32. The amount of catechin and metabolites excreted in urine was $20 \%$ higher $(P=0.06)$ after RW consumption than after DRW consumption.

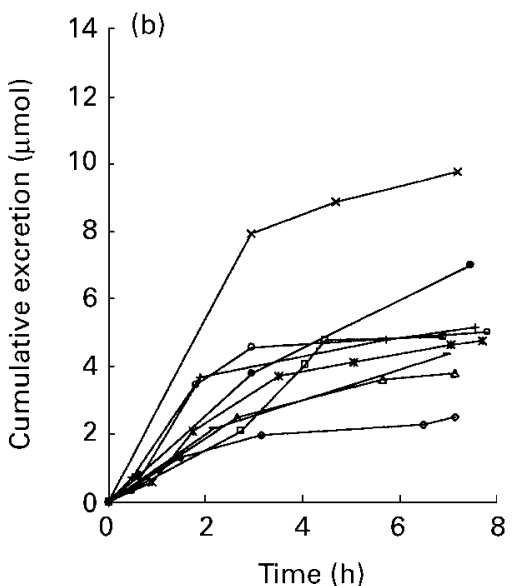


Table 1. Conjugated forms of catechin in urine from human subjects following consumption of $120 \mathrm{ml}$ red wine or de-alcoholized red wine*

(Mean values with their standard errors for nine subjects)

\begin{tabular}{|c|c|c|c|c|c|c|c|c|}
\hline \multirow{3}{*}{$\begin{array}{l}\text { Treatment .... } \\
\text { Metabolites† }\end{array}$} & \multicolumn{4}{|c|}{ Conjugate ( $\mu \mathrm{mol})$} & \multicolumn{4}{|c|}{ Conjugate (\% of total) } \\
\hline & \multicolumn{2}{|c|}{$\mathrm{RW}$} & \multicolumn{2}{|c|}{ DRW } & \multicolumn{2}{|c|}{ RW } & \multicolumn{2}{|c|}{ DRW } \\
\hline & Mean & SEM & Mean & SEM & Mean & SEM & Mean & SEM \\
\hline Catechin-free & 0.01 & 0.00 & 0.01 & 0.01 & 0.1 & 0.0 & 0.2 & $0 \cdot 2$ \\
\hline Catechin-sulfate & $2 \cdot 86$ & 0.65 & $2 \cdot 38$ & 0.55 & $40 \cdot 2$ & 3.5 & $42 \cdot 1$ & $5 \cdot 5$ \\
\hline Catechin-glucuronide & 0.24 & 0.04 & 0.28 & 0.06 & 3.6 & 0.5 & 4.6 & 0.9 \\
\hline Catechin-glucuronide-sulfate & $2 \cdot 21$ & $0 \cdot 14$ & $1 \cdot 68$ & 0.30 & 37.4 & $4 \cdot 0$ & 34.8 & $5 \cdot 7$ \\
\hline Sum of all unmethylated conjugates & $5 \cdot 32$ & $0 \cdot 71$ & $4 \cdot 35$ & 0.52 & $81 \cdot 3$ & 1.5 & $81 \cdot 8$ & $1 \cdot 0$ \\
\hline $3^{\prime} \mathrm{MC}-$ free & 0.09 & 0.04 & 0.07 & 0.02 & $1 \cdot 0$ & 0.3 & $2 \cdot 1$ & 0.4 \\
\hline $3^{\prime} \mathrm{MC}-$ sulfate & $0 \cdot 12$ & 0.03 & $0 \cdot 12$ & 0.33 & $1 \cdot 8$ & 0.2 & $12 \cdot 0$ & 0.9 \\
\hline 3'MC-glucuronide & 0.89 & $0 \cdot 15$ & 0.68 & 0.12 & $13 \cdot 6$ & 1.6 & $12 \cdot 0$ & $1 \cdot 2$ \\
\hline $3^{\prime} \mathrm{MC}$-glucuronide-sulfate & 0.17 & 0.06 & $0 \cdot 15$ & 0.05 & $2 \cdot 4$ & 0.7 & 3.0 & $1 \cdot 0$ \\
\hline Sum of all methylated conjugates & $1 \cdot 27$ & 0.23 & 1.02 & 0.17 & $18 \cdot 7$ & 1.5 & $18 \cdot 2$ & $1 \cdot 0$ \\
\hline Total (all metabolites) & $6 \cdot 6$ & 0.9 & $5 \cdot 3$ & 0.6 & & & & \\
\hline
\end{tabular}

RW, red wine; DRW, de-alcoholized red wine.

${ }^{*}$ For details of subjects and procedures, see p. 32.

† The total amount of catechin and metabolites excreted in urine was $20 \%$ higher after RW than after DRW $(P=0.06)$.

$\ddagger$ There were no significant differences in the percentages of individual conjugate forms after RW and DRW.

RW and DRW. The majority of these $3^{\prime}$ methylated metabolites were also conjugated with glucuronide. However, smaller levels $3^{\prime}$ methylated metabolites were also present as sulfate conjugates, glucuronide-sulfate conjugates or in unconjugated form.

Extremely small amounts of $4^{\prime}$ methylated metabolites were also excreted in urine. An average value of $0.027 \mu \mathrm{mol}$ were excreted after RW and an average value of $0.018 \mu \mathrm{mol}$ were excreted after DRW over the $8 \mathrm{~h}$ period. These metabolites accounted for $<0.5 \%$ catechin metabolites. Because the amounts of $4^{\prime}$ methylated metabolites in urine were so low, it was not possible to determine accurately all the forms of the conjugates in all urine samples. However, in the most concentrated urine samples (obtained $2-4 \mathrm{~h}$ after consumption), an average of $48 \%$ catechin metabolites were present as glucuronide conjugates, $10 \%$ as sulfate conjugates and $16 \%$ as both glucuronide and sulfate conjugates.

The percentages of the conjugate forms of catechin as well as $3^{\prime} \mathrm{MC}$ in the first urine samples (about $1 \mathrm{~h}$ ) and the final urine samples (about $8 \mathrm{~h}$ ) after RW consumption are shown in Fig. 2. The percentages of the conjugate forms in the first sample and the final sample were not significantly different.

\section{Discussion}

There is an inverse relationship between wine consumption and cardiovascular disease mortality (Renaud \& de Lorgeril 1992). Ethanol in wine appears to be responsible for only a fraction of the health benefits enjoyed by wine-drinking populations (St Leger et al. 1979; Klatsky \& Armstrong, 1993; Sasaki \& Kesteloot, 1994; Gronbæk et al. 1995). Flavonoids in wine may provide additional protection against cardiovascular disease by acting as antioxidants (de Whalley et al. 1990; Fuhrman et al. 1995; Whitehead et al. 1995; Cao et al. 1996; Serafini et al. 1996, 1998; Teissedre et al. 1996; Hayek et al. 1997; Nidgikar et al. 1998), or
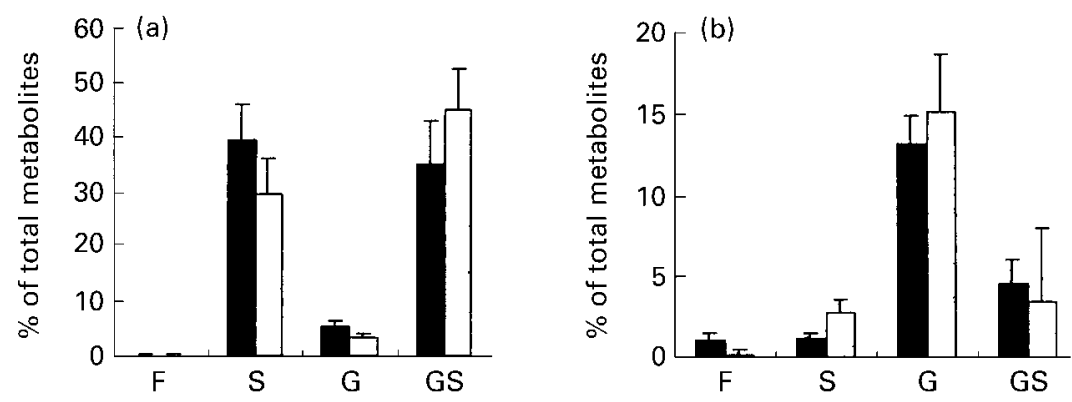

Fig. 2. Average percentages of the conjugated forms of catechin and $3^{\prime}-O$-methylcatechin in the first sample of urine (near $1 \mathrm{~h}$ ) and the last sample of urine (near $8 \mathrm{~h}$ ) following consumption of $120 \mathrm{ml}$ red wine with ethanol. (a), Un-methylated forms; (b), methylated forms. Forms were free $(F)$, sulfated $(S)$, glucuronidated $(G)$, or glucuronidated and sulfated (GS). $\mathbf{\square}$, First urine sample; $\square$, last urine sample. For details of subjects and procedures, see p. 32. Values are means for nine subjects with standard errors shown by vertical bars. There were no significant differences in the percentages of the conjugate forms in the early samples and the late urine samples. 
reducing platelet activity and counteracting the increased activity of platelets after ethanol withdrawal (Seigneur et al. 1990; Demrow \& Folts, 1994; Demrow et al. 1995; Ruf et al. 1995; Pace-Asciak et al. 1996; Renaud \& Ruf, 1996; Hayek et al. 1997; Osman et al. 1998, Rein et al. 2000b). Flavonoids also have anti-inflammatory and vasorelaxing activities (Fitzpatrick et al. 1993; Schramm et al. 1997). Understanding the contribution of each of these mechanisms to vascular health requires comprehensive knowledge of the metabolism, distribution and excretion of flavonoids in wine. It is not known if there are additional biological effects when flavonoids are consumed in the presence of ethanol. Flavonoids and ethanol are co-ingested in wine, but similar considerations can arise from the simultaneous consumption of other sources of ethanol with foods that contain flavonoids.

We previously reported that ethanol reduced the elimination half-life of total catechin after RW consumption without affecting the pattern of catechin metabolites (Donovan et al. 1999a; Bell et al. 2000). In the present study, $20 \%$ more catechin metabolites were excreted in urine over an $8 \mathrm{~h}$ period after RW compared with DRW. Although the significance level was not very high $(P=0 \cdot 06)$, this result, coupled with our previous finding in plasma does indicate a role of ethanol in enhancing the rate of catechin elimination. The urine volume was increased by $17 \%$ after wine with ethanol suggesting that the increased elimination is due to a diuretic effect (Rozman \& Klaassen, 1996). Further studies, however, are necessary to fully understand the effect of ethanol on the elimination of flavonoids as well as its mechanism of action.

Several investigators have measured the urinary excretion of other flavonoids and their conjugates after consumption of foods. In all of these studies, only a small fraction of the flavonoid dose was recovered in urine (Xu et al. 1994; Fuhr \& Kummert, 1995; Lee et al. 1995; Ameer et al. 1996; Nielsen et al. 1997, 1999; de Vries et al. 1998, 2001; Lapidot et al. 1998; Watanabe et al. 1998; Young et al. 1999). Another study showed that even when absorption of flavonol glycosides is $>50 \%$, elimination in urine is $<1 \%$ (Hollman et al. 1995).

We also found that only a small fraction of the dose of catechin is recovered in urine after RW consumption. In the present study we used a fairly short collection period, compared with other studies of flavonoid excretion. However, catechin has a much shorter half-life in plasma than other flavonoids (only 2-3h) and most metabolites were excreted during the first $4 \mathrm{~h}$ (see Fig. 1). Thus, $5 \%$ of the ingested dose represents the vast majority of catechin excreted by this mechanism after wine consumption.

Differences in the proportions of specific catechin metabolites in plasma and urine indicate that certain metabolites may not be exclusively eliminated by urine. Large, extensively conjugated metabolites are more likely to be eliminated by bile (Rozman \& Klaassen, 1996). Metabolites conjugated with both the glucuronide and sulfate residues made up the majority of catechin metabolites in plasma after wine consumption (Donovan et al. 1999a). However, these metabolites accounted for only $39 \%$ of the total catechin in urine, suggesting that biliary excretion may also be occurring. Conversely, the metabolites that were conjugated with just sulfate were rapidly eliminated from plasma, and their increased proportion in urine indicates that these metabolites are preferentially excreted in urine.

Some catechin may also have been eliminated in forms that do not contain the intact flavonoid ring as reported in the early studies by Das (1971) and Hackett et al. 1983. Recent experiments also indicate that microflora present in the large intestine can metabolise catechin as well as other flavanols to smaller phenolic acids and lactones (Meselhy et al. 1997; Déprez et al. 2000; Li et al. 2000). These metabolites were not measured in the present study as they can originate from many phenolic components in wine. However, this may represent an important elimination mechanism that should be investigated further in the future.

The results of the present study show that after RW consumption $3-10 \%$ ingested catechin is eliminated in urine over an $8 \mathrm{~h}$ period. They also suggest that ethanol reduced the elimination half-life of catechin in plasma by increasing elimination in urine. Differences in the proportions of individual metabolites in plasma and urine indicate that some metabolites are not eliminated exclusively in urine. Other mechanisms of elimination, such as excretion by bile and metabolism within the large intestine must be studied further for a complete understanding of the fate of flavonids in man.

\section{Acknowledgements}

We gratefully acknowledge the advice of Alan Buckpitt, Rosemary Walzem and Robert Hansen. Funding was provided by E\&J Gallo Winery, the Wine Spectator and the Wine Institute.

\section{References}

Ameer B, Weintraub RA, Johnson JV, Yost RA \& Rouseff L (1996) Flavanone absorption after naringin, hesperidin, and citrus administration. Clinical Pharmacology and Therapeutics 60, 34-40.

Arts ICW, Hollman PCH, Feskins EJM, de Mesquita HBB \& Kromhout D (2001) Catechin intake and associated dietary and lifestyle factors in a representative sample of Dutch men and women. European Journal of Clinical Nutrition 55, 76-81.

Arts ICW, van de Putte B \& Hollman PCH (2000a) Catechin contents of foods commonly consumed in The Netherlands. 2. Tea, wine, fruit juices, and chocolate milk. Journal of Agricultural and Food Chemistry 48, 1752-1757.

Arts ICW, van de Putte B \& Hollman PCH (2000b) Catechin contents of foods commonly consumed in The Netherlands. 1. Fruits, vegetables, staple foods, and processed foods. Journal of Agricultural and Food Chemistry 48, 1746-1751.

Bell JRC, Donovan JL, Wong R, Waterhouse AL, German JB, Walzem RL \& Kasim-Karakas SE (2000) (+)-Catechin in human plasma after ingestion of a single serving of reconstituted red wine. American Journal of Clinical Nutrition 71, 103-108.

Cao G, Sofic E \& Prior RL (1996) Antioxidant capacity of tea and common vegetables. Journal of Agricultural and Food Chemistry 44, 3426-3431.

Clifford AJ, Ebeler S, Ebeler JD, Bill ND, Hinrichs SH, Teissedre P-L \& Waterhouse AL (1996) Delayed tumor onset in transgenic mice fed an amino-acid diet supplemented with red wine solids. American Journal of Clinical Nutrition 64, 748-756. 
Criqui MH \& Ringel BL (1994) Does diet or alcohol explain the French paradox? Lancet 344, 1719-1723.

Das NP (1971) Studies on flavonoid metabolism and absorption and metabolism of (+)-catechin in man. Biochemical Pharmacology 20, 3435-3445.

Das NP \& Sothy SP (1971) Studies on flavonoid metabolism: biliary and urinary excretion of metabolites of $(+)-\left[\mathrm{U}-{ }^{14} \mathrm{C}\right]$ catechin. Biochemical Journal 125, 417-423.

Da Silva EL, Piskula M \& Terao J (1998) Enhancement of antioxidative ability of rat plasma by oral administration of (-)epicatechin. Free Radical Biology and Medicine 24, 1209-1216.

Day A, Bao Y, Morgan M \& Williamson G (2000) Conjugation position of quercetin glucuronides and effect on biological activity. Free Radical Biology and Medicine 29, 1234-1243.

Demrow HS \& Folts JD (1994) Gastric or IV administration of French red wine but not white wine inhibits in vivo platelet activity and thromobosis in stenosed canine coronary arteries. Journal of the American College of Cardiology 49A, Special Issue.

Demrow HS, Slane PR \& Folts JD (1995) Administration of wine and grape juice inhibits in vivo platelet activity and thrombosis in stenosed canine coronary arteries. Circulation 91, $1182-1188$

de Pascual-Teresa S, Santos-Buelga C \& Rivas-Gonzalo JC (2000) Quantitative analysis of flavan-3-ols in spanish foodstuffs and beverages. Journal of Agricultural and Food Chemistry 48, $5331-5337$.

Déprez S, Brézillon C, Rabot S, Philippe C, Mila I, Lapierre C \& Scalbert A (2000) Metabolism of polymeric proanthocyanidins by a human colonic microflora. Journal of Nutrition 130, $2733-2738$

de Vries JHM, Jeanne HH, Hollman PCH, Meyboom S, Busyman MNCP, Zock PL, Van Staveren WA \& Katan MB (1998) Plasma concentrations and urinary excretion of the antioxidant flavonols quercetin and kaempferol as biomarkers for dietary intake. American Journal of Clinical Nutrition 68, 60-65.

de Vries JHM, Hollman PCH, van Amersfoort I, Olthof MR \& Katan MB (2001) Red wine is a poor source of bioavailable flavonols in men. Journal of Nutrition 131, 745-748.

de Whalley CV, Rankin SM, Hoult JRS, Jessup W \& Leake DS (1990) Flavonoids inhibit the oxidative modification of low density lipoproteins by macrophages. Biochemical Pharmacology 39, 1743-1750.

Donovan JL, Bell JR, Kasim-Karakas S, German JB, Walzem RL, Hansen RJ \& Waterhouse AL (1999a) Catechin is present as metabolites in human plasma after consumption of red wine. Journal of Nutrition 129, 1662-1668.

Donovan JL, Luthria DL, Stremple P \& Waterhouse AL (1999b) Analysis of (+)-catechin, (-)-epicatechin and their $3^{\prime}$ and $4^{\prime}$ O-methylated analogs: A comparison of sensitive methods. Journal of Chromatography B 726, 277-283.

Fitzpatrick DF, Hirschfield SL \& Coffey RG (1993) Endotheliumdependent vasorelaxing activity of wine and other grape products. American Journal of Physiology 265, H774-H778.

Fuhr U \& Kummert AL (1995) The fate of naringin in humans: A key to grapefruit juice-drug interactions. Clinical Pharmacology and Therapeutics 58, 365-373.

Fuhrman B, Lavy A \& Aviram M (1995) Consumption of red wine with meals reduces the susceptibility of human plasma and low density lipoprotein to lipid peroxidation. American Journal of Clinical Nutrition 61, 549-554.

Grønbæk M, Deis A, Sorensen TIA, Becker U, Schnohr P \& Jensen G (1995) Mortality associated with moderate intakes of wine, beer and spirits. British Medical Journal 310, 1165-1169.

Gugler R, Leschik M \& Dengler HJ (1975) Disposition of quercetin in man after single oral and intravenous doses. European Journal of Clinical Pharmacology 9, 229-234.

Hackett AM, Griffiths LA, Broillet A \& Wermeille M (1983) The metabolism and excretion of $(+)-\left[{ }^{14} \mathrm{C}\right]$ cyanidanol-3 in man following oral administration. Xenobiotica 13, 279-283.

Hayek T, Fuhrman B, Vaya J, Rosenblat M, Belinky P, Coleman R, Elis A \& Aviram M (1997) Reduced progression of atherosclerosis in apolipopritein E-deficient mice following consumption of red wine, or its polyphenols quercetin or catechin, is associated with reduced susceptibility of LDL to oxidation and aggregation. Arteriosclerosis Thrombosis and Vascular Biology 17, 2744-2752.

Hertog MGL, Feskens EJM, Hollman PCH, Katan JB \& Kromhout D (1993) Dietary antioxidant flavonoids and risk of coronary heart disease: the Zutphen elderly study. Lancet 342, $1007-1011$

Hertog MGL, Kromhout D, Aravanis C, Blackburn H et al. (1995) Flavonoid intake and long-term risk of coronary heart disease and cancer in the seven countries study. Archives of Internal Medicine 155, 381-386.

Hollman PCH \& Arts ICW (2000) Flavonols, flavones, and flavanols - nature, occurrence and dietary burden. Journal of the Science of Food and Agriculture 80, 1081-1093.

Hollman PCH, de Vries JHM, van Leeuwen SD, Mengelers MJB \& Katan MB (1995) Absorption of dietary quercetin glycosides and quercetin in healthy ileostomy volunteers. American Journal of Clinical Nutrition 62, 1276-1282.

Hollman PCH, Trijp J, Mengelers MJB, Vries JHM \& Katan MB (1997) Bioavailability of the dietary antioxidant flavonol quercetin in man. Cancer Letters 114, 139-140.

Klatsky AL \& Armstrong MA (1993) Alcoholic beverage choice and risk of coronary artery disease mortality: Do red wine drinkers fare best? American Journal of Cardiology 71, 467-469.

Kühnau J (1976) The flavonoids, a class of semi-essential food components: their role in human nutrition. World Review of Nutrition and Dietetics 24, 117-191.

Lapidot T, Harel S, Granit R \& Kanner J (1998) Bioavailability of red wine anthocyanins as detected in human urine. Journal of Agricultural and Food Chemistry 46, 4297-4302.

Lee MJ, Wang ZY, Li H, Chen L, Sun Y, Gobbo S, Balentine DA \& Yang CS (1995) Analysis of plasma and urinary tea polyphenols in human subjects. Cancer Epidemiology Biomarkers and Prevention 4, 393-399.

Li C, Lee M-J, Sheng S, Meng X, Prabhu S, Winnik B, Huang B, Chung JY, Yan S, Ho C-T \& Yang CS (2000) Structural identification of two metabolites of catechins and their kinetics in human urine and blood after tea ingestion. Chemical Research in Toxicology 13, 177-184.

Manach C, Morand C, Crespy V, Demigne C, Texier O, Regerat F \& Remesy C (1998) Quercetin is recovered in human plasma as conjugated derivatives which retain antioxidant properties. FEBS Letters 426, 331-336.

Meselhy MR, Nakamura N \& Hattori M (1997) Biotransformation of (-)-epicatechin 3-O-gallate by human intestinal bacteria. Chemical and Pharmaceutical Bulletin 45, 888-893.

Nidgikar SV, Williams NR, Griffin BA \& Howard AN (1998) Consumption of red wine polyphenols reduces the susceptibility of low-density lipoproteins to oxidation in vivo. American Journal of Clinical Nutrition 68, 258-265.

Nielsen SE, Kall M, Justesen U, Schou A \& Dragsted LO (1997) Human absorption and excretion of flavonoids after broccoli consumption. Cancer Letters 114, 173-174.

Nielsen SE, Young JF, Daneshvar B, Lauridsen ST, Knuthsen P, Sandstrom B \& Dragsted LO (1999) Effect of parsley intake on urinary apigenin excretion, blood antioxidant enzymes and 
biomarkers for oxidative stress in humans. British Journal of Nutrition 81, 447-455.

Osman HE, Maaleg N, Shanmuganayagum D \& Folts JD (1998) Grape juice but not orange or grapefruit juice inhibits platelet activity in dogs and monkeys (Macaca fasciularis). Journal of Nutrition 128, 2307-2312.

Pace-Asciak CR, Rounova O, Hahn SE, Diamandis EP \& Goldberg DM (1996) Wines and grape juices as modulators of platelet aggregation in healthy human subjects. Clinica Chimica Acta 246, 163-182.

Plumb GW, de Pascual-Teresa S, Santos-Buelga C, Cheynier V \& Williamson G (1998) Antioxidant properties of catechins and proanthocyanidins: effect of polymerisation, galloylation and glycosylation. Free Radical Research 29, 351-358.

Rein D, Lotito S, Holt R, Keen C, Schmitz H \& Fraga C (2000a) Epicatechin in human plasma: In vivo determination and effect of chocolate consumption on plasma oxidation status. Journal of Nutrition 130S, 2109S-2114S.

Rein D, Paglieroni TG, Pearson DA, Wun T, Schmitz HH, Gosselin R \& Keen CL (2000b) Cocoa and wine polyphenols modulate platelet activation and function. Journal of Nutrition 130S, 2120S-2126S.

Renaud S \& De Lorgeril M (1992) Wine, alcohol, platelets and the French paradox for coronary heart disease. Lancet 339, $1523-1526$.

Renaud S \& Ruf J-C (1996) Effects of alcohol on platelet functions. Clinica Chimica Acta 246, 77-89.

Richelle M, Tavazzi I, Enslen M \& Offord EA (1999) Plasma kinetics in man of epicatechin from black chocolate. European Journal of Clinical Nutrition 53, 22-26.

Ritchey JG \& Waterhouse AL (1999) A standard red wine: monomeric phenolic analysis of commercial Cabernet Sauvignon wines. American Journal of Enology and Viticulture 50, $91-100$.

Rozman KK \& Klaassen CD (1996) Absorption, distribution and excretion of toxicants. In Casarett \& Doull's Toxicology: The Basic Science of Poisons, pp. 91-112 [KK Klaasen, editor]. New York, NY: McGraw-Hill.

Ruf JC, Berger JL \& Renaud S (1995) Platelet rebound effect of alcohol withdrawl and wine drinking in rats. Arteriosclerosis Thrombosis and Vascular Biology 15, 140-144.

Scalbert A \& Williamson G (2000) Dietary intake and bioavailability of polyphenols. Journal of Nutrition 130S, 2073S-2085S.

St Leger AS, Cochrane AL \& Moore F (1979) Factors associated with cardiac mortality in developed countries with particular reference to the consumption of wine. Lancet 1017-1020, May 12.

Sasaki S \& Kesteloot H (1994) Wine and non-wine alcohol: differential effect on all-cause and cause-specific mortality. Nutrition, Metabolism, and Cardiovascular Diseases 4, $177-182$.

Schramm DD, Pearson DA \& German JB (1997) Endothelial cell basal $\mathrm{PGI}_{2}$ release is stimulated by wine in vitro: one mechanism that may mediate the vasoprotective effects of wine. Nutritional Biochemistry 8, 647-651.

Schramm DD, Wang JF, Holt RR, Ensunsa JL, Gonsalves JL, Lazarus SA, Schmitz HH, German JB \& Keen CL (2001) Chocolate procyanidins decrease the leukotriene-prostacyclin ratio in humans and human aortic endothelial cells. American Journal of Clinical Nutrition 73, 36-40.

Seigneur M, Bonnet J, Dorian B, Benchimol D, Drouillet F, Gouverneur G, Larrue J, Crockett R, Boisseau M, RibereauGayon P \& Bricaud H (1990) Effect of the consumption of alcohol, white wine, and red wine on platelet function and serum lipids. Journal of Applied Cardiology 5, 215-222.

Serafini M, Ghiselli A \& Ferro-Luzzi A (1996) In vivo antioxidant effect of green and black tea in man. European Journal of Clinical Nutrition 50, 28-32.

Serafini M, Maiani G \& Ferro-Luzzo A (1998) Alcohol-free red wine enhances plasma antioxidant capacity in humans. Journal of Nutrition 128, 1003-1007.

Shaw IC \& Griffiths LA (1980) Identification of the major biliary metabolite of (+)-catechin in the rat. Xenobiotica 10, 905-911.

Shaw IC, Hackett AM \& Griffiths LA (1982) Metabolism and excretion of the liver-protective agent (+)-catechin in experimental hepatitis. Xenobiotica 12, 405-416.

So FV, Guthrie N, Chambers AF, Moussa M \& Carroll KK (1996) Inhibition of human breast cancer cell proliferation and delay of mammary tumorigenesis by flavonoids and citrus juices. Nutrition and Cancer 26, 167-181.

Teissedre PL, Frankel EN, Waterhouse AL, Peleg H \& German JB (1996) Inhibition of in vitro human LDL oxidation by phenolic antioxidants from grapes and wine. Journal of the Science of Food and Agriculture 90, 55-61.

Walle T, Eaton EA \& Walle UK (1995) Quercetin, a potent and specific inhibitor of the human P-form phenolsulfotransferase. Biochemical Pharmacology 50, 731-734.

Watanabe S, Yamaguchi M, Sobue T, Takahashi T, Miura T, Arai Y, Mazur W, Wahala K \& Aldercreutz H (1998) Pharmacokinetics of soybean isoflavones in plasma, urine and feces of men after ingestion of $60 \mathrm{~g}$ baked soybean powder (Kinako). Journal of Nutrition 128, 1710-1715.

Wermeille M, Turin E \& Griffiths LA (1983) Identification of the major urinary metabolites of (+)-catechin and 3-O-methyl-(+)catechin in man. European Journal of Drug Metabolism and Pharmacokinetics 8, 77-84

Whitehead TP, Robinson D, Allaway S, Syms J \& Hale A (1995) Effect of red wine ingestion on the antioxidant capacity of serum. Clinical Chemistry 41, 32-35.

Xu X, Harris KS, Wang H-J, Murphy PA \& Hendrich S (1995) Bioavailability of soybean isoflavones depends upon gut microflora in women. Journal of Nutrition 125, 2307-2315.

Xu X, Wang H-J, Murphy PA, Cook L \& Hendrich S (1994) Daidzein is a more bioavailable soymilk isoflavone than is genestein in adult women. Journal of Nutrition 124, 825-832.

Xu R, Yokoyama WH, Irving D, Rein D, Walzem RL \& German JB (1998) Effect of dietary catechin and vitamin E on aortic fatty streak accumulation in hypercholesterolemic hamsters. Atherosclerosis 137, 29-36.

Young JF, Dragsted LO, Daneshvar B, Lauridsen ST, Hansen M \& Sandstrom B (2000) The effect of grape-skin extract on oxidative status. British Journal of Nutrition 84, 505-513.

Young JF, Nielsen SE, Haraldsdottir J, Daneshvar B, Lauridsen ST, Knuthsen P, Crozier A, Sandstrom B \& Dragsted LO (1999) Effect of fruit juice intake on urinary quercetin excretion and biomarkers of antioxidative status. American Journal of Clinical Nutrition 69, 87-94. 